\title{
Chapter 10 \\ The Baltic Cod Trawl Fishery: The Perfect Fishery for a Successful Implementation of the Landing Obligation?
}

\author{
Daniel Valentinsson, Katja Ringdahl, Marie Storr-Paulsen, \\ and Niels Madsen
}

\begin{abstract}
The cod fisheries in the Baltic Sea were among the first EU fisheries with a full implementation of the EU Landing Obligation (LO) or so-called 'discard ban', phased in from 2015 onwards. This chapter describes key aspects for the successful management of Baltic cod such as the long history of scientific data collection for stock assessment and cod management as well as a well-documented history of work aimed at increased selectivity in cod trawls. We then analyse how the scientific data used for stock assessment has been affected by the LO and how the knowledge of Baltic cod selectivity has been used and developed since its introduction. We conclude that in spite of many good prerequisites, the introduction of the LO in Baltic cod fisheries has been unsuccessful and has failed to deliver any of the expected benefits. Data quality for stock assessments has deteriorated, discarding of cod has not decreased despite a reduced minimum size and there are no indications of increased gear selectivity in the fishery. Finally, we propose potential explanations for this failure and recommend actions that may be needed to make the Landing Obligation more successful.
\end{abstract}

Keywords Baltic Sea · Common fisheries policy · Discard ban · Discards · European Union · Regionalisation · Selectivity · Trawl

D. Valentinsson $(\bowtie) \cdot$ K. Ringdahl

Department of Aquatic Resources, Institute of Marine Research, Swedish University of Agricultural Sciences, Lysekil, Sweden

e-mail: daniel.valentinsson@slu.se

M. Storr-Paulsen

National Institute of Aquatic Resources, DTU-Technical University of Denmark, Lyngby, Denmark

N. Madsen

Department of Chemistry and Bioscience - Section of Biology and Environmental Science,

Aalborg University, Aalborg, Denmark 


\subsection{Introduction}

Baltic Sea cod was the first demersal species with a full implementation of the EU Landing Obligation (LO) in 2015. The LO meant that the dominant fisheries that use trawls and nets were phased-in at once, with only a survival exemption for the negligible cod catches from pots and traps valid between 2015 and 2017 (Commission Delegated Regulation (EU) No 1396/2014). Catches from cod trawls in the Baltic, in contrast to other European demersal trawl fisheries, are relatively clean with only flounder (non-quota species) and some plaice as notable bycatches. In 2017, plaice was also included in the Baltic Sea LO. This could potentially lead to challenges for some Baltic countries as the relative stability (i.e. the fixed allocation key of TAC between countries) means that few countries in the Baltic hold a relatively large share of the total plaice quota. This could potentially be problematic for the countries with no quota or with a very low quota share if they cannot avoid plaice in their cod catches.

Because bottom trawls are by far the main gear used to catch Baltic cod and because both gear selectivity research and discard observers programmes have a long history in the Baltic, the setting and background of this fishery seem perfect for a successful LO implementation. This chapter focuses on the prerequisites and outcomes of the LO in the Baltic trawl fishery targeting cod. Our aim is to describe the backdrop to the LO implementation and subsequent indications of the outcomes. We first describe the discard sampling using scientific observers and how these data are used in stock assessments. We also depict the long history of trawl selectivity research in Baltic cod trawls and then discuss the outcomes of these aspects in light of the articulated aims of the Landing Obligation (Anon 2018a), i.e., reduced unwanted catches, improved quality of scientific data and industry adaption through the adoption of more selective fishing practices.

\subsubsection{The Baltic Cod Stocks: Stock Development and Current Status}

The Baltic Sea is inhabited by two genetically distinct cod populations, i.e. eastern and western Baltic cod. There is evidence supporting the difference between the two populations, based on differences in spawning time, otolith shape (Hüssy et al. 2016) and genetics (Nielsen et al. 2003; Nielsen et al. 2005). The cod in the Baltic Sea live in brackish water characterized by low salinity and an oxygenated surface layer with a hypoxic deeper saline layer that gives a permanent halocline. This influences egg buoyancy and thereby egg survival, especially in the more eastern part of the Baltic Sea. The water volume suitable for egg fertilisation and development of eastern Baltic cod (i.e., the reproductive volume) is defined as the volume of water with a PSU $>12$ and oxygen content $>2 \mathrm{ml} / \mathrm{l}$ (Köster et al. 2003). 
Cod fisheries in the Baltic Sea have a long history (MacKenzie et al. 2002). More intensive exploitation only started in the 1950s (Bagge and Thurow 1994; Eero et al. 2007). The cod fishery on the eastern stock increased further in the early 1980s as a result of increased stock biomass due to favourable reproductive conditions and strong year classes (Eero et al. 2011). As the fishery intensified during the 1980s, a period of low productivity due to deteriorated environmental conditions began which, together with intensive exploitation, rapidly reduced the stock. In a 10 year period, the stock size was reduced by more than 85\% (ICES 2013), and in 2005 the spawning stock biomass was estimated to be at a historic low, close to $10 \%$ of the high levels observed in the 1980s. However, after 2005 the stock started to rebuild again and the positive developments were partly assigned to effective management measures and increased reproductive success. In 2010, the stock was thought to have recovered (Eero et al. 2012a). Shortly after, it was evident that although recruitment was estimated to be good, large cod were missing in scientific surveys and commercial catches. The nutritional condition of adult cod has been continuously declining since the 1990s. However, since the mid-2000s, when cod abundance started to increase again, the proportion of eastern cod with a very low condition index increased rapidly (ICES 2017a). The reasons for deteriorating nutritional condition and possibly reduced growth are not fully understood. Different hypotheses are suggested including: (i) low prey availability in the area where cod are mainly found (Eero et al. 2012b); (ii) increased size selectivity in commercial fisheries which may have led to high mortality of large cod, (iii) a greater proportion of small-sized fish in the stock and their contribution to density-dependent effects and (iv) increased extent of low oxygen areas that could affect cod growth either directly via physiological processes or indirectly via affecting benthic prey availability (Chabot and Dutil 1999; Svedäng and Hornborg 2014; Eero et al. 2015; Casini et al. 2016). In 2017 the eastern Baltic cod stock was estimated to be at a very low level and cod larger than $45 \mathrm{~cm}$ were very scarce (ICES 2018).

The western Baltic cod spawns in specific areas in saline waters deeper than 20-40 m, with the main spawning areas being the Little and the Great Belt, the Sound and the Kiel and Mecklenburg Bays. The western Baltic cod mixes with both the eastern Baltic cod stock in the Arkona Basin (Subdivision 24) and with the Kattegat cod stock in the southern part of Kattegat (ICES 2018). The western Baltic cod stock has also experienced large fluctuations in stock development over time. In the mid-1980s, landings were close to $50,000 \mathrm{t}$ in the western Baltic management area to below $6000 \mathrm{t}$ in 2017. Unlike the eastern Baltic cod, there is no documentation of decreased condition or impairment by reduced growth of western Baltic cod. The western Baltic cod has experienced high fishing pressure and shown poor recruitment for several years and was assessed to be well below reference points at the onset of the LO in 2015. However, although the spawning stock was at a historically low level in 2016, a new large year class was observed, which is likely to influence the development of the stock in the following years (ICES 2018). 


\subsection{Data Collection and Assessment of Baltic Cod}

Internationally coordinated management of the two Baltic cod stocks stems back to the early 1970s. Before many of the countries around the Baltic Sea joined the EU, the management authority was the International Baltic Sea Fishery Commission (IBSFC), which ceased to exist in 2007. The two cod stocks were regulated together by a total Baltic TAC (total allowable catch) until 2003, but have since then been regulated separately. The introduction of a TAC in the late 1980s was prompted by the drastic decline in stock size and catches in the mid 1980s, just after the peak in stock size when catches exceeded 400,000 t (Bagge and Thurow 1994; Suuronen et al. 2007). The first EU management plan for Baltic cod was introduced in 2007 (Council Reg (EC) No 1098/2007). The cod plan was repealed in the summer of 2016 when a new multi-annual plan for all Baltic stocks of cod, herring and sprat was introduced (Reg (EU) No 2016/1139).

The assessment of the eastern Baltic cod stock was conducted for many years as a full age-based analytical assessment. In 2014, however, ICES could no longer accept the assessment. There were several factors that had changed the prerequisite for the assessment: Ageing discrepancies between countries, reduced growth and the unexplained disappearance of larger cod despite the appearances of good recruitment. Therefore, a reliable analytical assessment could not be produced. The advice since 2015 has been based on the so-called ICES "category three" assessments. These assessments mainly use trends in an index of spawning stock or total biomass from research surveys. The current assessment approach for the eastern stock uses the numbers of cod above $30 \mathrm{~cm}$ (as a proxy for Spawning Stock Biomass, SSB) from the survey where the average abundance for the two most recent years is divided by the average for the three previous years (" 2 over 3 rule"). Thus, the provision of high quality management advice is challenged by a number of changes in cod biology and the ecological conditions affecting cod (ICES 2017a). The change of assessment methodology drastically changed the perception of the eastern stock and resulted in a large reduction in the advised quota in contrast to quota increases in previous years. Since 2015 TACs have been set well above advised quotas but have not been fully utilised (ICES 2018), meaning that quotas have been non-restrictive in some Member States. Before 2015, individual cod were assigned to their stock of origin (western or eastern cod) only according to the area where they were caught. This was changed in 2015 when a split on the cod caught in the transition area (SD 24) was applied, assigning the individual cod in the transition area to either stock based on otolith shape analyses and genetics. A consequence of the split was that it was not possible to use the full time series back to 1970 as before, but the time series had to be truncated to 1994. In 2013, substantial recreational catches were also included in the western Baltic cod stock assessment (ICES 2013). This was one of the first stocks in Europe to take recreational catches into account in fisheries management advice. The western stock assessment is still conducted as a full age-based analytical assessment, because it is not facing the severe uncertainties, such as the absence of large cod and impaired growth, observed among eastern cod. 
The quantities of cod discarded by Baltic cod trawlers have been estimated based on data collected by on-board observers on commercial fishing vessels since 1996 (early from an EU perspective). Since 2002 the monitoring has been done under the EC data collection regulations (EU No 199/2008, Commission Decision 2010/93/ EU, EU No 2017/1004, Commission Decision 2016/1251/EU). The objective of the monitoring programme is exclusively scientific and the observers have no role in control and enforcement. The observers measure the volume of discarded catches and species and size composition of all the catch (discards and retained). All relevant biological information concerning discards is also recorded. Discard estimates for the eastern Baltic cod stock were included in the assessment of the stock between 2001-2014, until the assessment method changed. Since 2015 discards are included in the advice as part of the harvest rate and ICES advice is based on total catches (landings and discards). For the western Baltic cod discard data have been included in the assessment since 2002.

For a long time the discards of cod in the Baltic were considered relatively low compared with other areas. The average discard rate in the western Baltic cod stock was 8\% (for the time period 1994-2017), and for the last three years (2015-2017) has been estimated at lower than 5\% (ICES 2018). For the eastern stock, the discard rate was low at the beginning of the time-series but has increased considerably over time. In 2017 the discard rate was estimated at 11\% (ICES 2018). Moreover, after a peak in 2013-2014, just before the introduction of the LO, the estimated discard rate fell but is still above long-term average for the stock (Fig. 10.1). Important to note is that MCRS (minimum conservation reference size) was reduced from 38 to $35 \mathrm{~cm}$ when the LO was introduced, which is a probable reason for the drop in discard rate

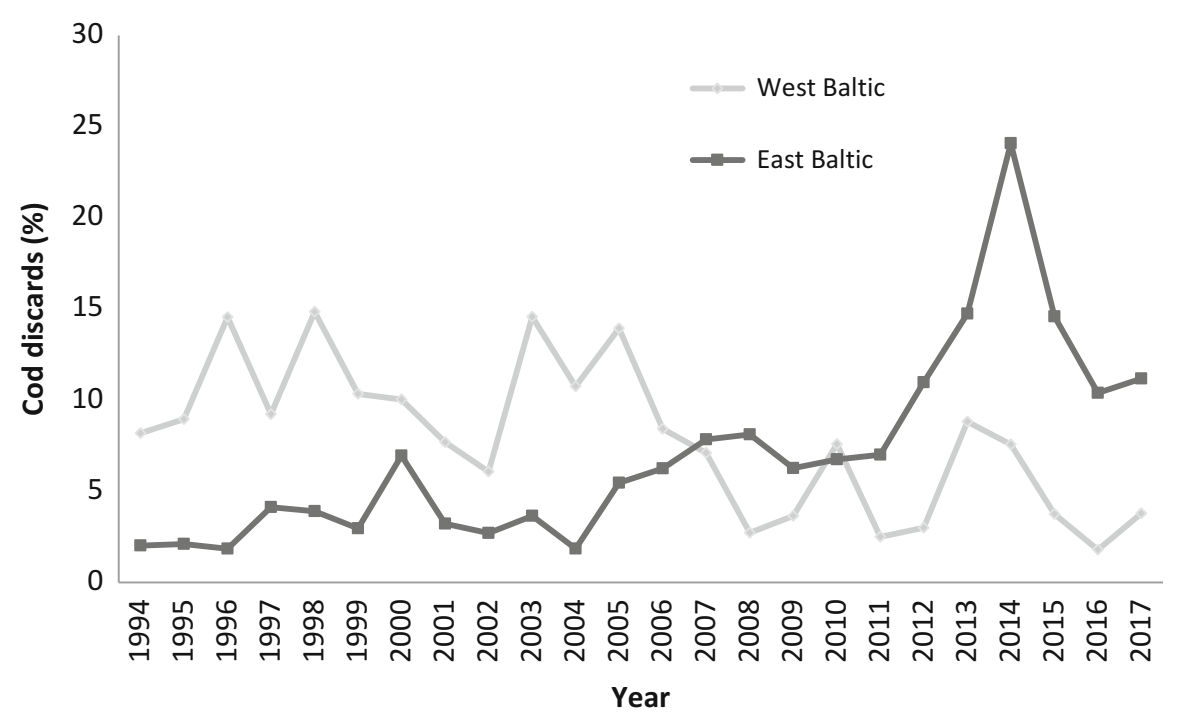

Fig. 10.1 Weight percentage of cod discarded between 1994 and 2017 for the Eastern and Western Baltic cod stocks. Catches combined from all gears (passive and active). (Data from ICES 2018) 
in 2015. Furthermore, problems in gaining observer access in some countries led ICES to point out that the discard estimate is highly uncertain and is also considered to be an underestimate (ICES 2017c).

The observer coverage of at-sea sampling programmes is usually low (Uhlmann et al. 2014). In the Swedish and Danish programmes, typically only $0.5-1.5 \%$ of the fishing trips are covered. Discard data are also known to be highly variable in terms of quantities and proportions (Kelleher 2005), which makes estimates of overall volumes of discarded fish uncertain. In Sweden, for example, the proportion of cod below MCRS ranged between 2\% and 43\% in observed trips during 2012-2017.

\subsection{Research to Improve Selectivity in Baltic Cod Trawls}

Technical conservation measures have a long history in the Baltic Sea. Documented scientific trials with escape windows to reduce catches of young fish in trawls started over 100 years ago (Ridderstad 1915), and the Baltic Sea is an area where many documented selectivity experiments have been carried out (see Madsen 2007). Improving the yield of Baltic cod by increasing size selectivity (length of first capture) and reducing discards have been a management strategy for decades. A series of scientific experiments have followed with the aim of developing and identifying new concepts to improve selectivity in the trawl fishery. As such, the L50 (50\% retention length) in a traditional diamond mesh codend can be increased by increasing the mesh size. However, a major focus in the Baltic Sea has been to make the selection curve steeper, which can be assessed by a lowered selection range (SR: L75-L25). By lowering SR, the escape of fish below a defined length (minimum landing or minimum conservation reference size; MLS or MCRS, respectively) is increased and the loss of marketable cod is reduced. This is important for the fishers because they do not want to lose any marketable fish. Fig. 10.2 illustrates the influence of SR for the retention of small and legal sized cod. Furthermore, to guarantee optimal selection, it is important that the selectivity is stable. The selectivity in traditional diamond mesh codends is normally reduced with increased catch weight due to closure of the mesh opening (Robertson and Stewart 1988; Tschernij and Holst 1999).

A common solution to improve trawl selectivity is to fit the net with an escape window ("window"), i.e., a panel with meshes (type and size) suitable to allow unwanted catch to escape. Typically, square mesh (netting turned $45^{\circ}$ ) panels are inserted into the net (mainly in the codend region), which ensures that meshes stay open in this region. The remaining part of the trawl is most often made of traditional diamond mesh netting. An advantage of the window is that it can be mounted directly in the existing trawl at low cost. Several types of windows have been tested in the Baltic Sea cod fishery over the years (Madsen 2007). The first tested selective codends were equipped with two side windows (known as the "Swedish window" codend), positioned close to the end of the codend (Tschernij et al. 1996). This codend had a higher selection factor (SF: 50\% retention length L50/mesh size) and 


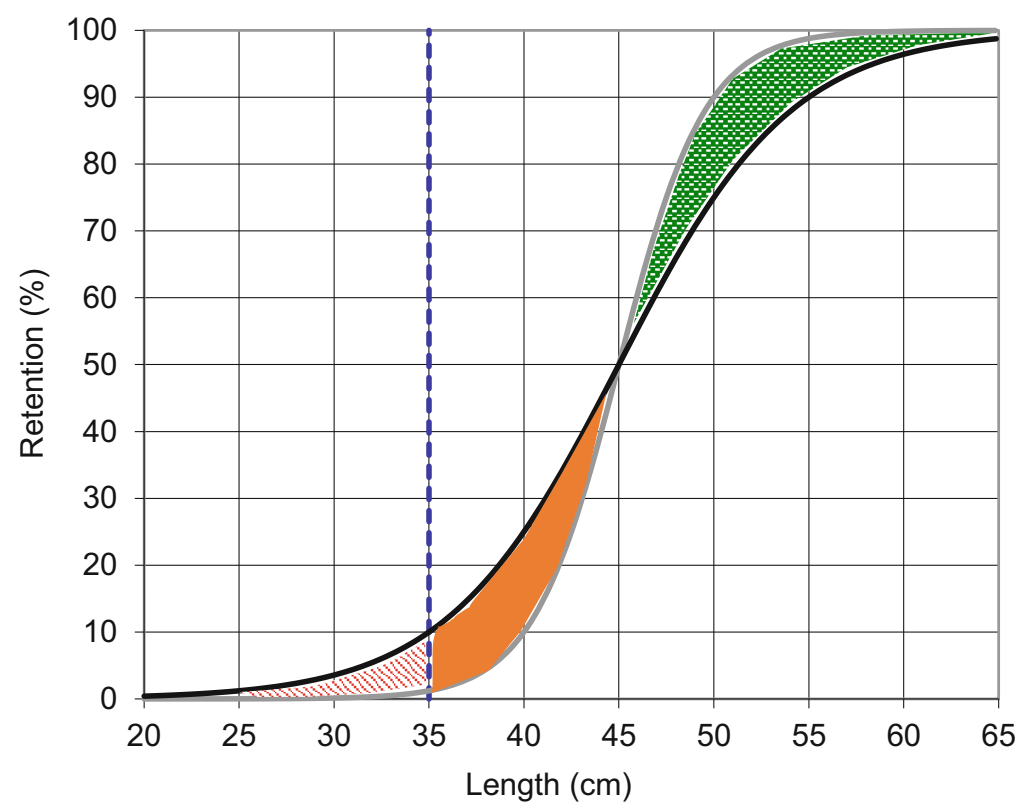

Fig. 10.2 Two hypothetical selection curves with identical L50 $(45 \mathrm{~cm})$ but with different selection ranges (SR). The grey curve has a lower SR $(5 \mathrm{~cm})$ and the black one, a higher SR $(10 \mathrm{~cm})$. Minimum size $(35 \mathrm{~cm})$ is indicated by the vertical dashed line. The red shaded area indicates differences in retention of undersized cod (higher retention with higher SR), the orange area indicates differences in retention of cod just above minimum size (higher retention with higher $\mathrm{SR}$ ) and the green area indicates the difference in retention for larger sizes (higher retention with lower SR)

lower relative selection range (SRA: selection range SR/L50) than a standard diamond mesh codend (Madsen 2007). This was also true when compared to a window codend having side windows ending in front of the lifting strop (known as the "Danish window" codend; Lowry et al. 1995; Madsen et al. 1998). Later experiments demonstrated that the selectivity is improved when the window is moved all the way back to the end of the codend (Madsen 2000) and even further using a codend with a single top window (Madsen 2007). These findings formed the basis for the "Bacoma window" (Fig. 10.3) used today. The idea behind the Bacoma window was to change the selectivity by changing the mesh size in the escape window only (Madsen et al. 2002). This was expected to make stepwise changes easier and to reduce costs compared to extensive changes to the entire gear. Experiments indicated that the SF was relatively constant when mesh size was changed in the window (Madsen et al. 2002). An additional advantage of the Bacoma codend was that it is more flexible and easier to handle than a full square mesh codend. However, the knotless netting used in the window is relatively expensive and difficult to mend (Tschernij and Suuronen 2002). 


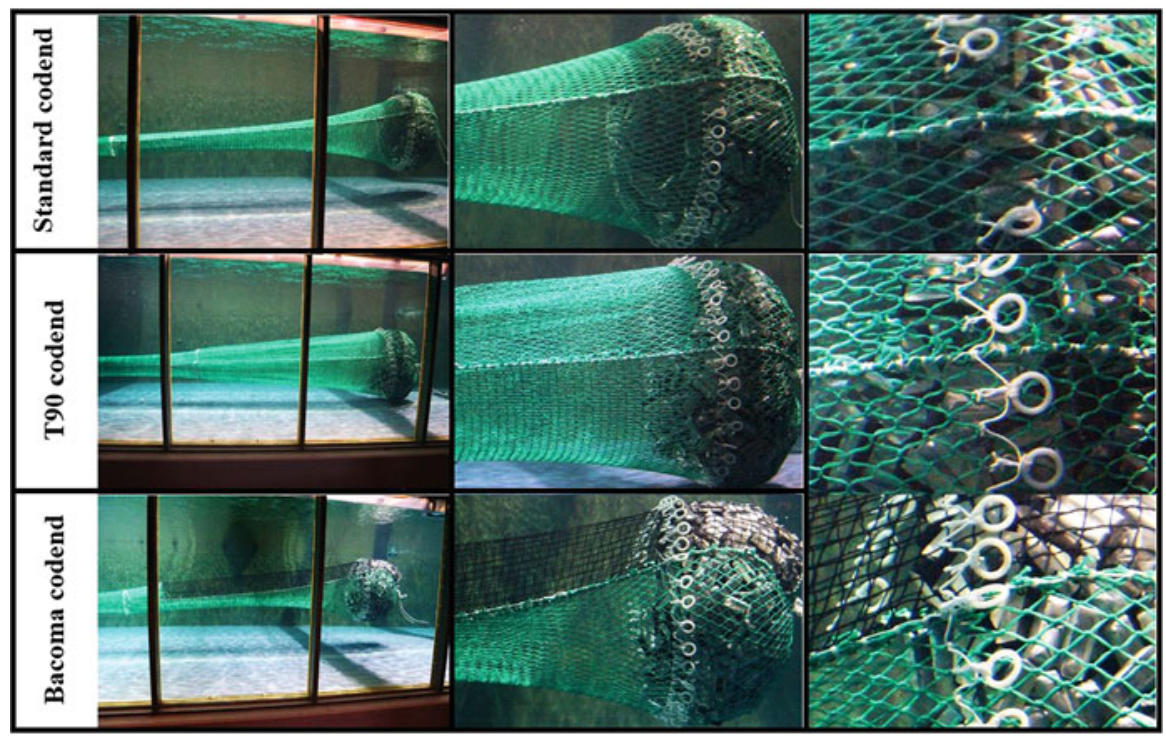

Fig. 10.3 The standard codend used before introducing selective codends and the T90 and Bacoma codend used today with a simulated $500 \mathrm{~kg}$ catch, tested inside the flume tank in Hirtshals, Denmark. In the left column the full codend, in the middle column the last part of the codend where the catch is stored and in the right column the meshes in the area around the lifting strops. (Details about the codends are found in Madsen et al. 2015)

During the last decade scientists have focused on the selective properties of T90 meshes in the Baltic Sea cod fishery (ICES 2011). The T90 codend is a very simple and cheap way to improve the size selectivity of a trawl, because standard conventional netting material can be used. In T90 codends, the standard (T0) diamond mesh netting is turned $90^{\circ}$, which provides a more open mesh under pull (Fig. 10.3). The netting knot size, netting material and codend circumference will influence selectivity (Herrmann et al. 2007; Wienbeck et al. 2011).

In recent years there has been a change in some EU countries where the typical top-down focus (from managers or scientists) of gear research initiatives has become less pronounced, and focus has shifted to bottom-up initiatives where the fishing industry identifies gear issues and develop solutions to better suit their fisheries (see O'Neill et al., this volume). Some of these initiatives are described in ICES (2017b). There are several explanations for this trend. Apart from the obvious ones such as increased transparency, and industry expert knowledge regarding gears and practical know-how regarding their fisheries and catches, another important factor is changes in EU policy. Examples are increased regionalisation and the introduction of the Landing Obligation with its associated choke issues (Borges and Penas Lado, this volume) and a movement to more results-based management with less prescriptive legislation in the reformed CFP. Bottom-up initiatives can also increase industry buy-in and thus help to alleviate some of the mistrust of top-down science and 
legislation and circumvention of rules and recommendations (Suuronen et al. 2007; Catchpole and Gray 2010; Krag et al. 2016).

Examples of recent or ongoing bottom-up gear related initiatives in the Baltic region are projects like MINIDISC and FastTrack in Denmark and the Selective Fisheries Secretariat in Sweden. The MINIDISC project evaluated the effectiveness of reducing unwanted catches through free gear choice and full documentation (Mortensen et al. 2017). Interestingly, the study reported that although the chosen gears indicated a lowered selectivity, the discard ratio decreased due to either higher landings or lower discards. However, as the technical descriptions of gears and fishing behaviour was limited, it is possible that changes other than gear selectivity might have influenced the results of the study. The FastTrack project and the Selective Fisheries Secretariat are very similar in terms of objectives, set-up and work procedures (Valentinsson 2016, www.fast-track.dk). Both involve an initial selection process of industry ideas where managers, industry and scientific representatives are involved. Accepted projects start with an iterative test and development phase of the gear modification in commercial practice led by the industry participants where they collect some data. A second phase is a scientific trial and evaluation. The large majority of projects within these two initiatives is focused on an improvement and documentation of the available toolbox of gears available for use by fishers to adapt to the LO (Valentinsson 2016).

Three of the projects under the Selective Fisheries Secretariat have focused on reducing unwanted catches in Baltic cod trawl fishery (Nilsson et al. 2018). One project was unsuccessful in reducing the catch of small cod; another showed increased selectivity but included a technically complex gear that cannot be used due to several conflicts with current regulations. The third project studied a modified T90 codend (slightly reduced mesh size, increased codend length and increased circumference). Those results showed that the modified codend reduced the catches of undersized cod (Nilsson 2018). Based on these results, a joint recommendation from BALTFISH in May 2017 to COM suggested allowing this T90 codend as an alternative. After evaluation by STECF, COM approved the recommendation and the new T90 codend was introduced February 1st, 2018 (Commission Delegated Regulation (EU) 2018/47).

\subsubsection{Technical Conservation Measures - the Baltic History}

The intensive research on improving the selectivity in Baltic cod trawls has led to several legislative changes since 1995. Before that, regulations for cod trawls stipulated a minimum mesh size of $105 \mathrm{~mm}$ and a minimum landing size (MLS) of $33 \mathrm{~cm}$. In 1994 the IBSFC changed the technical measures, which was followed by a series of changes over the next decade. From 1995, the baseline mesh size was increased to $120 \mathrm{~mm}$ and MLS to $35 \mathrm{~cm}$ in order to protect young cod. By derogation a $105 \mathrm{~mm}$ codend remained allowed if one of two designs of exit windows was used. This was one of the first EU regulations where selective devices were adopted into 
legislation (Council EC regulation No 2250/95; Madsen 2007; Feekings et al. 2013). The technical descriptions of the two windows (Danish and Swedish) were very detailed; this was the start of a practice that continued in the following Baltic trawl specifications. In 1998 these gear rules were transposed into EU legislation (Council Reg (EC) No. 88/98). Based on advice from a large international scientific project (the Bacoma project, Suuronen et al. 2000), starting in 2002, IBSFC changed both exit windows with two alternative codends. This meant that either a $130 \mathrm{~mm}$ codend or a new codend with $105 \mathrm{~mm}$ mesh size and a knotless square mesh window of $120 \mathrm{~mm}$ (i.e., the Bacoma codend) had to be used. Use of the Bacoma codend was widespread in early 2002 but due to the increased L50 $(\sim 10 \mathrm{~cm})$, initial catch losses for trawlers that used the Bacoma codend were substantial (Tschernij et al. 2004). Therefore, most trawlers rapidly switched to the alternative $130 \mathrm{~mm}$ diamond mesh codend or manipulated their Bacoma codends to decrease selectivity (Suuronen et al. 2007), with increased discarding as a result. This led to an EU emergency closure of Baltic cod fisheries in April 2003. When the fishery reopened in August 2003, the Bacoma panel mesh size was reduced to $110 \mathrm{~mm}$, conventional diamond mesh codends were prohibited and cod MLS was increased to $38 \mathrm{~cm}$. The changed mesh size was supposed to better match the new $38 \mathrm{~cm}$ MLS (Valentinsson and Tschernij 2003). In 2005 the current technical regulation (Council Reg (EC) No 2187/2005) was introduced and the $110 \mathrm{~mm}$ Bacoma codend was allowed. For a few years, the $110 \mathrm{~mm}$ Bacoma codend was the only legally approved gear. In 2006, a T90 codend was introduced as an alternative after an evaluation of existing data by ICES, which did not find any difference in selectivity between the $110 \mathrm{~mm}$ T90 codend and the $110 \mathrm{~mm}$ Bacoma (ICES 2007; Suuronen et al. 2007). The next major change occurred in 2010 when the mesh size of the T90 codend and the Bacoma window was increased from $110 \mathrm{~mm}$ to $120 \mathrm{~mm}$ to further decrease catches of juvenile cod. The length of the Bacoma window was also extended. The latter measure was to prevent selectivity from decreasing at high catch rates (Madsen et al. 2010). A follow-up analysis of Danish discard data demonstrated that these improvements in selectivity contributed to a reduction of cod discards (Feekings et al. 2013).

In 2014 the regionalisation within the reformed CFP gave Member States more power over technical regulations as part of temporary discard plans in accordance with articles 15(6) and 18(3) of the basic Regulation (Regulation (EU) No 1380/ 2013). The Member States around the Baltic Sea, organised in the regional group called Baltfish, suggested in their first joint recommendation to the Commission that the minimum conservation reference size (MCRS) should be lowered from 38 to $35 \mathrm{~cm}$ as an "efficient and speedy way to minimise cod discards" when the Landing Obligation was introduced 2015 (Anon 2014a). The commission adopted this proposal in their discard plan for 2015-2017 and prolonged it via a delegated act from 2018 (delegated regulation No. 2018/306). The new alternative $115 \mathrm{~mm}$ T90 codend was introduced on first February 2018 after a joint recommendation from Baltfish (Commission delegated regulation (EU) 2018/47). This was the first change to Baltic cod trawl regulations since 2010 .

Expected changes in size selectivity of Baltic cod trawls over the time period 1994-2018 is shown in Fig. 10.4, where the estimated L50 values and minimum 


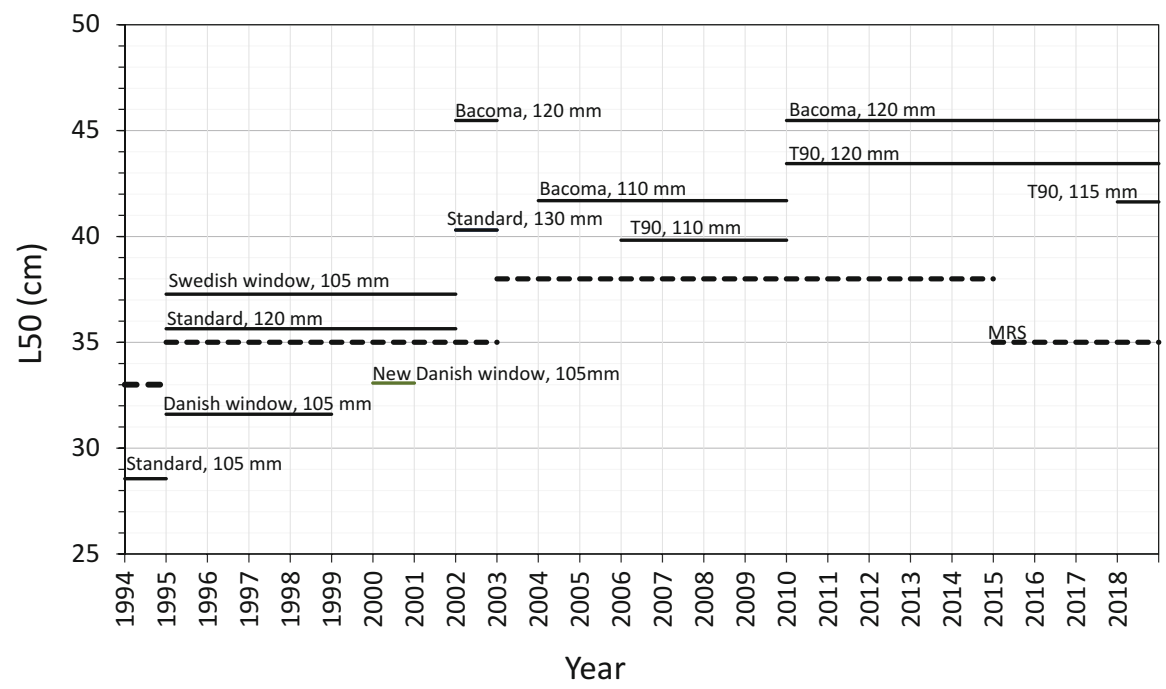

Fig. 10.4 Changes in estimated codend selectivity (L50) in Baltic cod trawls during the past 25 years (some information from Feekings et al. 2013). The minimum mesh opening was set to $120 \mathrm{~mm}$ (Bacoma) from January 1st, 2010 in subdivisions 22-24 (western Baltic) and from March 1st, in sub-Divisions 25-32 (Eastern Baltic). The L50 for the T90 $120 \mathrm{~mm}$ codend is taken from Wienbeck et al. (2011). All other L50 values are taken from Madsen (2007). The same selectivity estimates are assumed for the Bacoma $120 \mathrm{~mm}$ and the new Bacoma $120 \mathrm{~mm}$ introduced in 2010

sizes over time are indicated. The estimated effect from the changes in selectivity is a continuous increase in L50, giving a total increase of about $15 \mathrm{~cm}$ since the early 1990s. This seems to be in conflict with the high discard rates reported in recent years. One reason could be that the estimated selectivity obtained from scientific sea trials does not necessarily reflect the realised selectivity in commercial practice because vessel type, engine power, gear choice, - design and -configuration may all influence selectivity. More information about commercial fishing practice and compliance is necessary to clarify this. In fact, the manipulation of the selectivity in trawls by fishers has been documented (ICES 2017c). Another potential reason is the considerable change in size structure of (mainly Eastern) Baltic cod; small individuals now dominate the stock and very few individuals are larger than $45 \mathrm{~cm}$ (ICES 2018). Thus, although the trawls used may be size selective, the catches still have a large proportion of small cod due to the truncated size structure of the fished population.

\subsubsection{Technical Conservation Measures - Since the Introduction of the Landing Obligation}

The dynamic period of many changes regarding technical measures for Baltic cod trawls in the 2000s was followed by a calmer period after 2010 (Fig. 10.4). However, 
renewed calls for changes to the technical measures emerged with the LO introduction for Baltic cod in 2015. Industry representatives in the Baltic Sea advisory council have repeatedly declared that the current detailed gear measures have hampered the implementation of the LO, and that a new technical framework with more flexibility is urgently needed (BSAC 2017). In 2015 industry representatives of the Baltic Sea Advisory Council (BSAC) had already recommended amending Reg. 2187/2005 by deleting the reference to the specifications of Bacoma and T90 to allow the use of $105 \mathrm{~mm}$ codends as under pre-1995 law (BSAC 2015). Despite all of the existing science and historical regulatory changes, gear measures are still today hotly debated in regional forums and Member States, especially in light of the Landing Obligation and unabated discarding. As mentioned above, information from the industry and observers suggests that trawls are being modified to reduce selectivity, leading to catching a higher proportion of smaller fish (ICES 2017c). This is not a new phenomenon in the Baltic (Valentinsson and Tschernij 2003; Suuronen et al. 2007). ICES (2007) also mentioned that considerable differences in opinion prevailed among Member States and that scientific arguments have gotten lost in a largely emotional debate. This may be one explanation for the lack of cooperation on this issue. Strikingly, in spite of $>3$ years with the LO and its increased mandate for regional proposals via discard plans, only one joint recommendation for an alternative trawl has been proposed. For control and documentation measures, joint recommendations are equally scarce from the Baltfish regional group of Member States.

A new technical framework regulation is now being negotiated in the EU. Available draft texts seem to consolidate the current two codends $(120 \mathrm{~mm}$ Bacoma or $120 \mathrm{~mm}$ T90) as minimum requirements, with options to adopt joint recommendations from regional groups for alternative gear measures, provided they are at least equivalent in terms of limiting unwanted catches as compared to the baseline gears. In essence, the revision of the technical measures framework does not represent a great change, as regional gear proposals (and control measures) have already been possible via discard plans since the introduction of the $\mathrm{LO}$ (art. 15(6) of Regulation (EU) No. 1380/2013).

\subsection{Effects of the Landing Obligation on Scientific Data for Stock Assessments}

When the Landing Obligation went into effect, it was expected to generate more accurate data because all catches of species that came under this obligation should have been documented and landed. During the years preceding the LO, there were even discussions about whether scientific sea-sampling programmes would still be needed (Anon 2014b; STECF 2014), as it appeared to be more cost-efficient to sample landed catches than board vessels at sea. Proper documentation and landing unwanted catches was also the underlying assumption for increased quotas, as landing quotas would be turned into catch quotas, based on historical discard estimates. 
In reality, however, 3 years of the LO in the Baltic Sea trawl fisheries for cod indicate that a majority of the unwanted catches of cod are neither brought ashore nor documented properly. In Sweden, for example, $2-4 \%$ of the total cod landings in the fisheries statistics were reported as cod below MCRS (recorded as below minimum size or 'BMS' in log books) between 2015 and 2017 (Fig. 10.5a). The estimated
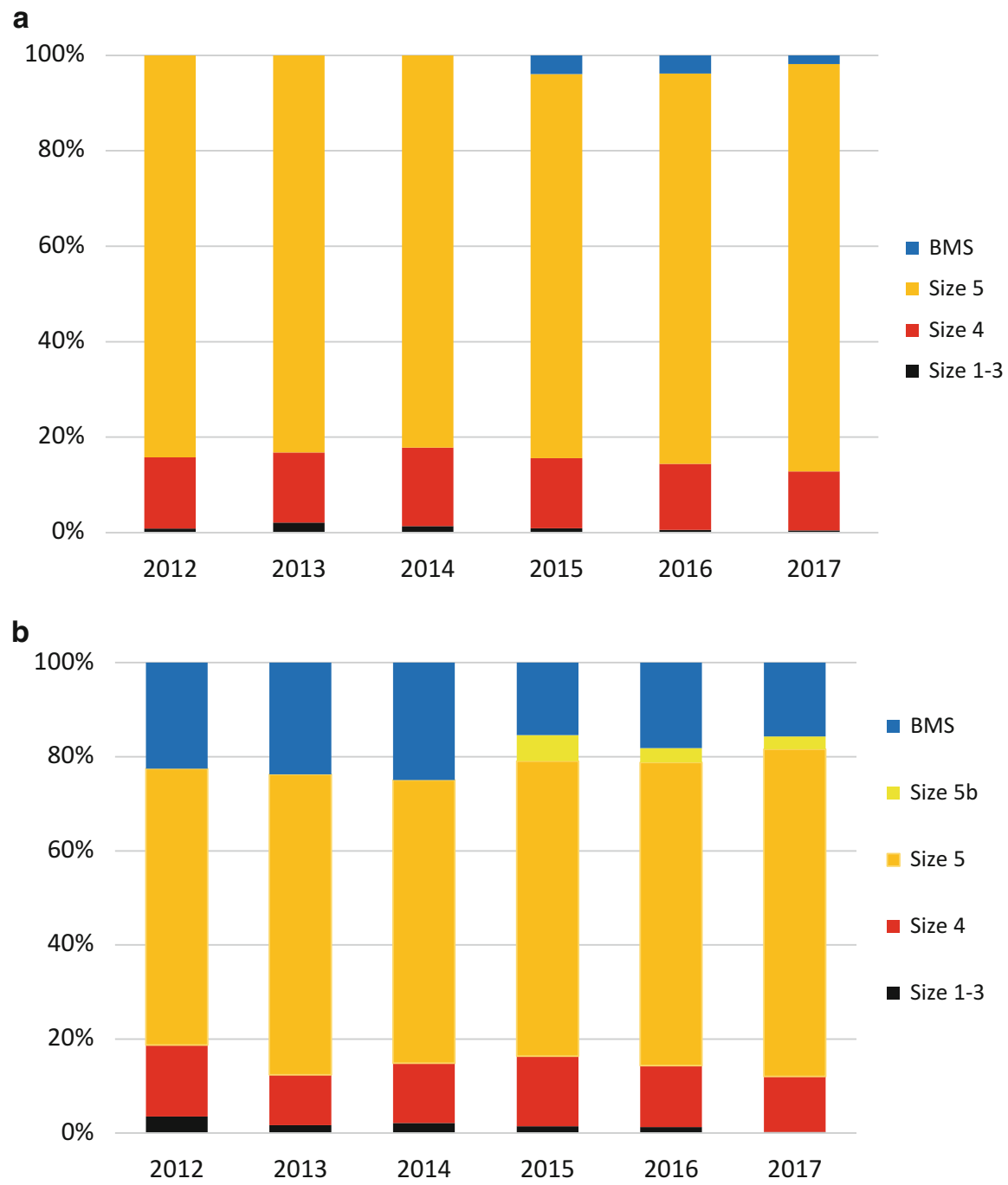

Fig. 10.5 Relative size composition of cod catches from Swedish Baltic trawl fisheries between 2012 and 2017 from (a) reported catches (logbooks and sales slips) and (b) data from the scientific observer programme. Size 1-3 are cod with an individual weight $>2 \mathrm{~kg}$, size 4 are cod in the range of $1-2 \mathrm{~kg}$ and size 5 are cod with an individual weight between 0.3 and $1 \mathrm{~kg}$. $5 \mathrm{~b}$ are cod with a length 35-37 cm. BMS are cod smaller than the minimum conservation reference size (MCRS)/ minimum landing size (MLS). MLS was $38 \mathrm{~cm}$ until 2015 and MCRS $35 \mathrm{~cm}$ from 2015 onwards 


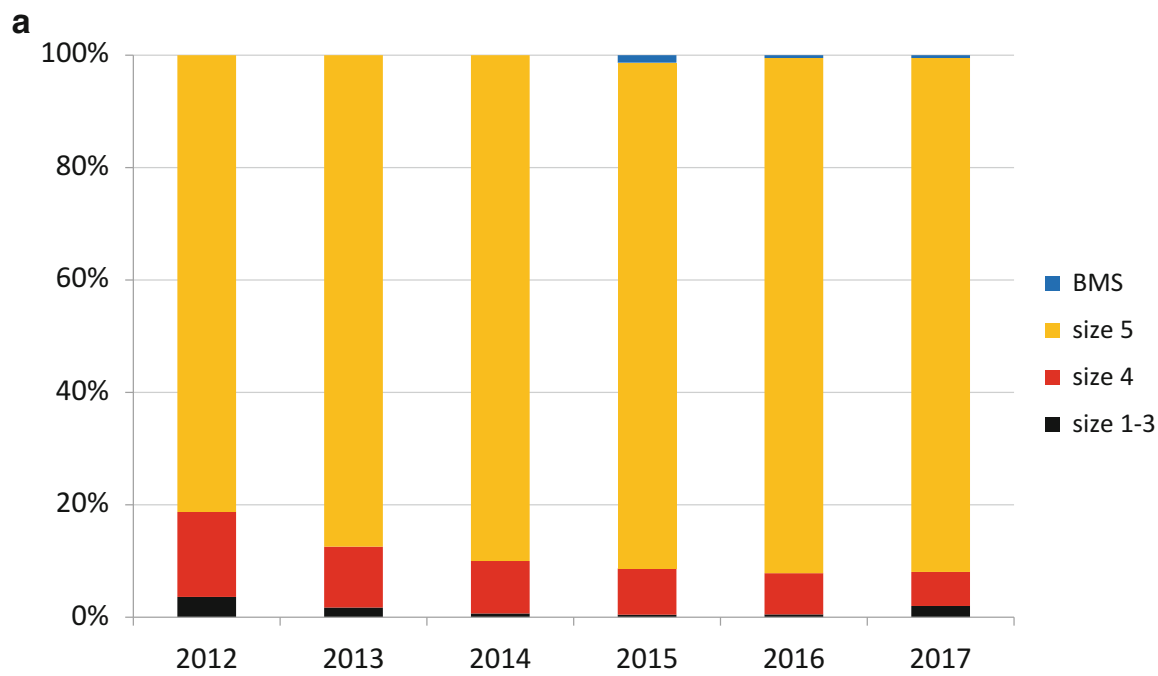

b

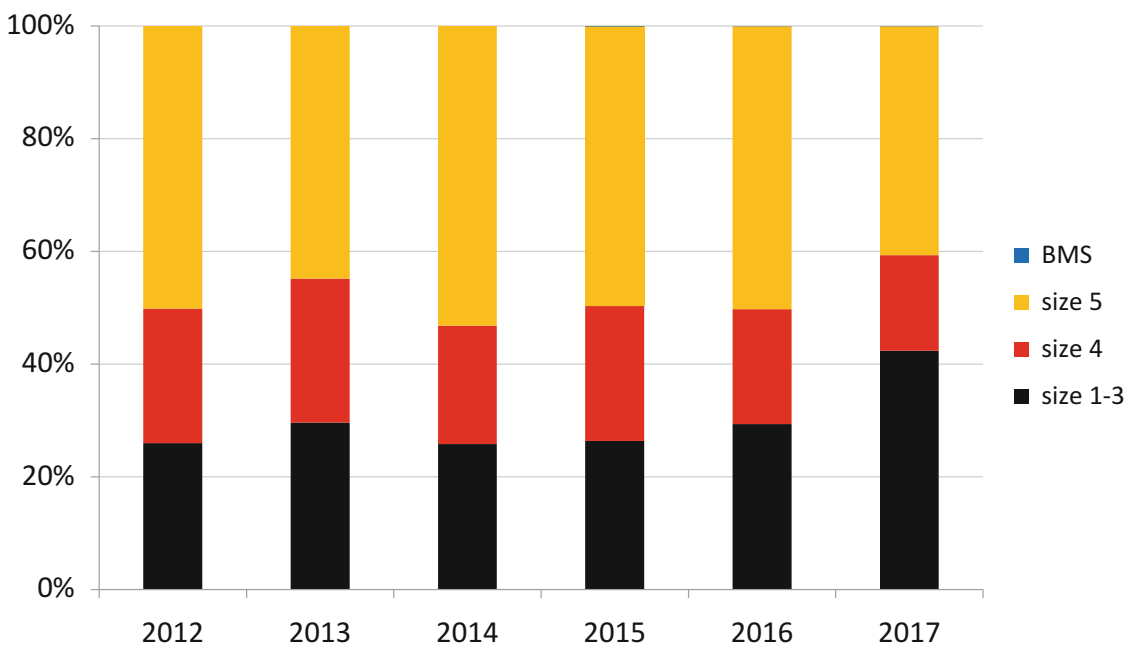

Fig. 10.6 Relative size composition of cod catches from Danish trawl fisheries based on logbooks and sale slips between 2012 and 2017 in the (a) Eastern and (b) Western Baltic Sea

discard rate from the at-sea sampling programme was $15-18 \%$ (Fig. 10.5b), indicating substantial underreporting of BMS cod. In reality, seagoing observers noted that most of the BMS cod were discarded. Similarly, $0.5-1.5 \%$ of the total landings in Denmark are reported as BMS for the eastern Baltic cod (Fig. 10.6a) and less than $1 \%$ for the western Baltic cod (Fig. 10.6b). Average discard rates from observer trips for the same years vary between 23 and 9\%, respectively, indicating that most of the BMS cod is discarded and is also unreported by Danish vessels. Several reasons may 
explain why the BMS fraction of the catch may not be landed: resistance to changing well-established commercial fishing practices (i.e. from legally discarding to being forced to land small fish); and primarily economic reasons, because it is illegal to sell the BMS fish for human consumption purposes and valorisation options may be underexplored (see also Iñarra et al., this volume). Other reasons may include a lack of buyers and inconvenient handling processes of small cod. In some fisheries, highgrading is still considerable. In these fisheries it seems rather unlikely that the BMS fraction will be landed as long as the enforcement is weak. In the Baltic, however, high-grading has not been considered to be a major problem because there is a market for smaller cod.

The amount of unwanted catches of cod decreased somewhat after the LO was introduced in 2015 (Fig. 10.5b). This decrease is partly a consequence of the reduction in MCRS from $38 \mathrm{~cm}$ to $35 \mathrm{~cm}$ that occurred at the same time (the $35-38 \mathrm{~cm}$ cod is labeled as 'size $5 \mathrm{~b}$ ' in Fig. 10.5b). Landings of the commercial sizes of cod from the Swedish observer trips are also shown. Failure to land unwanted cod catches and report them is widespread and observed far beyond Sweden and Denmark. The proportion of BMS cod landings as reported to ICES by all countries was less than $1 \%(0.7 \%$ for eastern Baltic and $0.5 \%$ for western Baltic cod). The assessment working group could thereby not rely on these reported figures as total catches and have therefore used data on unwanted cod from observer programmes instead (ICES 2018).

The European Fisheries Control Agency (EFCA) coordinates the Member States in a control monitoring programme (i.e. last haul; see Nuevo et al., this volume). The objectives are to evaluate compliance with the LO, to compile catch composition data for use in a risk management strategy and to provide information about where and when discards are expected in a particular fishery. Last haul data are not easily available for scientific use. Data acquired from the last haul inspections do not provide all needed biological information and vessels are not selected at random. However, last haul data are an important source of catch information that can be used to validate data from the scientific observer programmes (e.g. by ICES WGBFAS). Better availability of detailed last haul data is therefore needed for scientific purposes. In both Sweden and Denmark, the observed catches below MCRS from the last haul controls have been similar to those estimated from the observer programmes. For example, Swedish last haul data for 2016/17 indicated $12.5 \%$ unwanted catches of cod, which is similar to the estimate from the observer data (Fig. 10.5b). Note that both these estimates are considerably larger than self-reported BMS catches by fishers (Fig. 10.5a). Data obtained from the last haul inspections are not easily available nor are they made public due to the confidentiality and potential implications of compliance breaches. Knowledge of unwanted cod catches and exploitation pattern on the stock thereby still heavily rely on data from the scientific sea-sampling programmes that are publically available, primarily through different scientific reports (STECF 2017; ICES 2018), but which may suffer from a significant observer bias (see below).

The introduction of the Landing Obligation has impacted the quality of scientific observer data as well. EU vessels are legally required to allow observers on board. In 
practice, however, scientific observers only board vessels after permission by the skipper when minimum safety standards are met. In Sweden, the initial response from the fishing industry was strongly opposed to the policy in 2015 when Baltic cod was phased into the LO. This opposition led to denial of observer access to many of the vessels. Sweden was only able to conduct 5 out of 24 planned observer trips on cod trawlers in the Baltic (Anon 2015), leading to the first time that discard estimates could not be provided to ICES. In response, in 2016 the Swedish Agency for Marine and Water Management (the responsible agency) changed the national legislation to fine vessels selected for sampling since 2016 if they refuse to take observers without a valid reason. Denmark did not have the same problem as Sweden initially but the sensitivity of the skippers' willingness to take observers became apparent after a national media debate during early 2018. A news story reported on the discrepancy between quantities of landed and self-reported BMS cod by fishers in contrast to those from scientific observer estimates from Danish trips (Anon 2018b). The examples from both countries highlight the risks for scientific data collection. STECF has expressed concern that increased refusal rates are causing a deterioration in data quality for scientists, and has requested more information on observer refusal rates from Member States (STECF 2016).

Introduction of the LO might introduce other types of biases than restricted access to all active vessels. Before 2015, discarding was not only legal but also even mandatory for undersized catches. When this act became illegal in 2015, the role of observers thus changed from documenting a legal act to documenting an illegal act. This could lead to an increased observer effect, i.e. that fishers change their behaviour when observers are aboard (Kelleher 2005; Anon 2014b; STECF 2016). Fishers can change their behavior in the presence of an observer in several ways: by changing fishing grounds for places were small fish occur less frequently; by changing gear; and by not discarding fish that they normally would discard. Introduction of the LO thereby requires more validation of observer data to control for these potential biases.

\subsection{Conclusions - Lessons from the Landing Obligation in the Baltic Cod Trawl Fishery and Future Prospects}

We have described that the intentions and expected benefits of the EU Landing Obligation have not been fulfilled after more than 3 years of the LO in the Baltic cod trawl fishery:

(i) Discarding of unwanted catches still occurs at rates roughly comparable to the years before the Landing Obligation, in spite of a lowered MCRS at the onset of the LO in 2015. In fact, there are even indications that discarding may have increased.

(ii) Coupled to the continued discarding of cod, there is also an important element of bad timing and bad luck. The timing of the introduction of the Landing 
Obligation for Baltic cod was fixed in the basic Regulation (Reg (EU) No 1380/ 2013) but coincided with a period of negative developments for the larger eastern Baltic cod stock. The reduced growth and condition and a truncated size distribution without larger cod forced the fishery to target cod around the minimum size. This inevitably resulted in unwanted catches due to the inherent selection range in trawls. The western cod stock was also in a depleted state with continuous TAC reductions since before the LO introduction in 2015. These factors have caused severe economic implications for the fisheries, affected the industry perspective of the future, and thus most likely complicated the LO implementation for the Baltic cod stocks.

(iii) The aim of improved data quality for stock assessment has not been met. The required documentation and landing of unwanted catches is at least an order of magnitude lower than estimated volumes from independent estimates by scientific observer programmes and last haul inspections. Fishermen consistently underreport catches, thus the stock assessments done by ICES cannot rely on official catch data only, but needs to include observer data. At the same time, the role of observers has most likely changed with the LO as they are now supposed to observe and quantify an illegal act. This change has resulted in data shortages due to increased refusal rates of access to vessels and may also have changed the representativeness of the estimates due to a changed observer effect. These trends therefore indicate that scientific data quality has not improved but rather worsened. As unwanted catches are underreported, continued catch sampling from scientific observers is a prerequisite for reliable data. Given the uncertainty of observer data in the LO context, the EFCA lasthaul inspections can potentially also provide independent information of unwanted catches although care must be taken due to certain limitations of the sampling methods. The data from these inspections are not easily available however, even for scientific purposes. This needs to change: to make evaluations of observer data possible, to (potentially) increase the quality of stock assessments, and to make the best use of limited public funding. One issue related to stock assessment quality effects of the LO is also the untimely discovery of major biological uncertainties for the eastern stock that negatively affected preparedness for the LO. The uncertainties led ICES to downgrade the assessment from a full analytical assessment to an index based assessment, which also changed the perception of stock status (and advised TAC) negatively just when the LO was introduced in 2015. The discontinuation of the analytical assessment negatively affected the understanding of stock status and development (including year class variability). Furthermore, the index based assessment currently applied does not use discard data, although these are still important for the catch advice from ICES. Large research initiatives are currently occurring in the Baltic countries in order to understand the biological uncertainties and to enable a rollback to full analytical assessment for eastern Baltic cod (ICES 2017a). The western stock assessment is still conducted as a full age-based analytical assessment. Still, implementation of the LO was most 
likely aggravated by reduced TACs, due to several years of reduced stock size and poor recruitment, before and after the onset of the LO in 2015.

(iv) There are no indications of increased gear selectivity since the introduction of the LO. In fact, there are even anecdotal reports of gear manipulation by fishers to reduce selectivity (ICES 2017c). The increased regional mandate to propose modifications to the current detailed and prescriptive gear regulations via joint recommendations has only been used once so far. This is surprising given the long and voluminous history of scientific selectivity trials, the more recent bottom-up gear research initiatives on Baltic cod trawls, the heated debate around continued discarding and the persistent criticism of current trawl specifications. More constructiveness and responsibility from Member States and regional groups is needed to create positive change and to facilitate the industry to adapt their trawls to the LO requirements. As mentioned above (Conclusion, ii), the lack of larger cod has resulted in increased unwanted catches due to the selection range in trawls. If selectivity (as reported) is further negated by gear manipulation to reduce losses of legal sized cod in this fishery, that struggles with economic viability, this of course further increases the unwanted catches.

(v) So what is needed to make the Landing Obligation work? The expectation that the LO would encourage fishers to avoid unwanted fish is based on an elegant idea but will most likely remain a pious hope until enforcement and incentives are aligned with that goal. The theoretical mechanism behind the expectation is that the LO will result in less unwanted catch via increased gear selectivity (or avoidance) based on the idea that unwanted catches costs quota and are less lucrative than wanted catch. The cost of unwanted fish is thereby supposed to be internalised for the fisher (Catchpole et al. 2017). This internalisation of costs will, however, not be realised if the risk of being caught discarding remains as insignificant as it is today. One of the key challenges is thus to shift the control and monitoring focus to what actually happens at sea, including the use of technologies like remote electronic monitoring (EM; see James et al., this volume). However, given that available control resources are not infinite, it is also essential to develop strong incentives to encourage best practice mitigation methods or behaviours (see Kraak and Hart, this volume). Based on the Baltic experiences so far, the calls for increased flexibility to allow fishers to choose gear solutions probably need to be coupled to increased documentation responsibility for fishers that opts in on freer gear choice (cf. Mortensen et al. 2017). An example of a sound supportive incentive could be to create a twin-tier structure and only allocate the estimated discard share of the quota to vessels that opt to use gears with a proven higher selectivity or that have full documentation via EM, and at the same time subtract the estimated discards from the quota for vessels that opt out of these measures. Such a structure would also be in accordance with Member States' responsibilities for the allocation of quotas in the basic regulation (art. 17 of Reg (EU) No 1380/2013). Other forms of incentives worth exploring may be to stimulate uptake of trawls with desirable selectivity by granting exclusive access to fishing locations (e.g. Real Time Closures RTCs and/or permanent 
areas) or time periods for fishers who opt to increase selectivity (Madsen and Valentinsson 2010; Condie et al. 2014). Experiences from other areas with discard bans indicate that such additional management measures are required to incentivise a move towards more selective fishing under a discard ban (MRAG 2007; Condie et al. 2014).

\section{References}

Anon. (2014a). Baltfish Joint Recommendation No 1, 27 May, 2014. 28 pp. http://www.bsac.dk/ Anon. (2014b). Report of the regional co-ordination meeting for the Baltic (RCM Baltic). 151 pp. https://datacollection.jrc.ec.europa.eu/docs/rcm/2014

Anon. (2015). Annual report for the Swedish national programme for collection of fisheries data 2015. 60 pp. https://datacollection.jrc.ec.europa.eu/ars/2015

Anon. (2018a). Discarding and the landing obligation. https://ec.europa.eu/fisheries/cfp/fishing rules/discards_en

Anon. (2018b). http://www.fiskerforum.dk/erhvervsnyt/a/dtu-smidt-i-land-af-vrede-fiskere20022018

Bagge, O., \& Thurow, F. (1994). The Baltic cod stock: Fluctuations and possible causes. ICES Marine Science Symposia 198, 254-268.

Borges, L., \& Penas Lado, E. (this volume). Discards in the common fisheries policy: The evolution of the policy. In S.S. Uhlmann, C. Ulrich, S.J. Kennelly (Eds.), The European Landing Obligation - Reducing discards in complex multi-species and multi-jurisdictional fisheries. Cham: Springer.

BSAC. (2015). The Baltic Sea Advisory Council's recommendations on technical measures. 29th September 2015. Ref: BSAC/2015/6. 4 pp. http://www.bsac.dk/BSAC-Resources/BSAC-State ments-and-recommendations

BSAC. (2017). BALTFISH / BSAC / EFCA joint workshop on monitoring, control and enforcement of the Landing Obligation. 9th March 2017. Final Report. 6 pp. http://www.bsac.dk/ meetings

Casini, M., Käll, F., Hansson, M., Plikshs, M., Baranova, T., Karlsson, O., et al. (2016). Hypoxic areas, density dependence and food limitation drive the body condition of a heavily exploited marine fish predator. Royal Society Open Science, 3, 160416.

Catchpole, T.C., \& Gray, T.S. (2010). Reducing discards of fish at sea: A review of European pilot projects. Journal of Environmental Management, 91(3), 717-723.

Catchpole, T.L., Riberio-Santos, A., Mangi, S.C., Hedley, C., Gray, T.S. (2017). The challenges of the landing obligation in EU fisheries. Marine Policy, 82, 76-86.

Chabot, D., \& Dutil, J.D. (1999). Reduced growth of Atlantic cod in non-lethal hypoxic conditions. Journal of Fish Biology, 55, 472-491.

Condie, H.M., Grant, A., Catchpole T.L. (2014). Incentivising selective fishing under a policy to ban discards; lessons from European and global fisheries. Marine Policy, 45, 287-292.

Eero M., Köster F.W., Plikshs M., Thurow F. (2007). Eastern Baltic cod (Gadus morhua callarias) stock dynamics: Extending the analytical assessment back to the mid-1940s. ICES Journal of Marine Science, 64, 1257-1271.

Eero, M., Mackenzie, B.R., Köster F.W., Gislason, H. (2011). Multi-decadal responses of a cod (Gadus morhua) population to human-induced trophic changes, fishing, and climate. Ecological Applications, 21(1): 214-226.

Eero M., Köster F.W., Vinther, M. (2012a). Why is the Eastern Baltic cod recovering? Marine Policy, 36 (1): 235-240. 
Eero, M., Vinther, M., Haslob, H., Huwer, B., Casini, M., Storr-Paulsen, M., et al. (2012b). Spatial management of marine resources can enhance the recovery of predators and avoid local depletion of forage fish. Conservation Letters, 5, 486-492.

Eero, M., Hjelm, J., Behrens, J., Buchmann, K., Cardinale, M., Casini, M., et al. (2015). Eastern Baltic cod in distress: Biological changes and challenges for stock assessment. ICES Journal of Marine Science, 72 (8), 2180-2186.

Feekings, J. P., Lewy, P., Madsen, N. (2013). The effect of regulation changes and influential factors on Atlantic cod discards in the Baltic Sea demersal trawl fishery. Canadian Journal of Fisheries and Aquatic Sciences, 70, 534-542.

Herrmann, B., Priour, D., Krag, L. (2007). Simulation-based study of the combined effect on cod-end size selection of turning meshes by $90^{\circ}$ and reducing the number of meshes in the circumference for round fish. Fisheries Research, 84, 222-232.

Hüssy, K., Mosegaard, H., Albertsen, C.M., Nielsen, E.E., Hemmer-Hansen, J., Eero, M. (2016). Evaluation of otolith shape as a tool for stock discrimination in marine fishes using Baltic Sea cod as a case study. Fisheries Research, 174, 210-218.

ICES. (2007). Report of the ICES advisory committee on fishery management, advisory committee on the marine environment and advisory committee on ecosystems. ICES advice. Book 8, 147 pp. Section 8.3.3.3: ICES response to EU on selectivity of active gears targeting cod in the Baltic Sea.

ICES. (2011). Report of the study group on turned $90^{\circ}$ codend selectivity, focusing on Baltic cod selectivity (SGTCOD). 4-6 May 2011, ICES Headquarters, Copenhagen. ICES CM 2011/ SSGESST:08. $44 \mathrm{pp}$.

ICES. (2013). Report of the Baltic Fisheries Assessment Working Group (WGBFAS), 10-17 April 2013, ICES Headquarters, Copenhagen. ICES CM 2013/ACOM:10. 747 pp.

ICES (2017a). Report of the Workshop on Biological Input to Eastern Baltic Cod Assessment (WKBEBCA), 1-2 March 2017. ICES CM 2017/SSGEPD: 19. 40 pp.

ICES (2017b). Interim report of ICES-FAO Working Group on Fishing Technology and Fish Behaviour (WGFTFB), 4-7 April 2017, Nelson, New Zealand. ICES CM 2017/SSGIEOM: 13.

ICES. (2017c). Cod (Gadus morhua) in subdivisions 24-32, eastern Baltic stock (eastern Baltic Sea). ICES advice on fishing opportunities, catch and effort. Version 4: 8 March 2018. 10 pp. https://doi.org/10.17895/ices.pub.3096.

ICES. (2018). Report of the Baltic fisheries assessment working group (WGBFAS), 6-13 April 2018, ICES Headquarters, Copenhagen, Denmark. ICES CM 2018/ACOM:11.

Iñarra, B., Bald, C., Cebrián, M., Antelo, L.T., Franco-Uría, A., Vázquez, J.A., Pérez-Martín, R., Zufía, J. (this volume). What to do with unwanted catches: Valorisation options and selection strategies. In S.S. Uhlmann, C. Ulrich, S.J. Kennelly (Eds.), The European Land-ing Obligation - Reducing discards in complex, multi-species multi-juridictional fisheries. Cham: Springer.

James, K.M. Campbell, N., Viðarsson, J.R., et al. (this volume). Tools and technologies for the monitoring, control and surveillance of unwanted catches. In S.S. Uhlmann, C. Ulrich, S.J. Kennelly (Eds.), The European Landing Obligation - Reducing discards in complex multi-species and multi-jurisdictional fisheries. Cham: Springer.

Kelleher, K. (2005). Discards in the world's marine fisheries. An update. FAO Fisheries Technical Paper. 470. 131 pp.

Köster, F.W., Schnack, D., Möllmann, C. (2003). Scientific knowledge of biological processes that are potentially useful in fish stock predictions. Scientia Marina, 67 (1), 101-127.

Kraak, S.B.M, \& Hart, P.J.B. (this volume). Creating a breeding ground for compliance and honest reporting under the Landing Obligation: Insights from behavioural science. In S.S. Uhlmann, C. Ulrich, S.J. Kennelly (Eds.), The European Landing Obligation - Reducing discards in complex multi-species and multi-jurisdictional fisheries. Cham: Springer.

Krag, L.A., Herrmann, B., Feekings, J., Karlsen, J.D. (2016). Escape panels in trawls - A consistent management tool? Aquatic Living Resources, 29, 306.

Lowry, N., Knudsen, L.H., Wileman, D.. (1995). Selectivity in Baltic cod trawls with square mesh codend windows. ICES CM, 1995/B:5. 
MacKenzie, B.R., Alheit, J., Conley, D.J., Holm, P., Kinze, C.C. (2002). Ecological hypotheses for a historical reconstruction of upper trophic level biomass in the Baltic Sea and Skagerrak. Canadian Journal of Fisheries and Aquatic Sciences, 59, 173-190.

Madsen, N. (2000). Experimental adjustments of the escape window position in trawl codends implications for Baltic Sea cod fishery. Meddelanden från Havsfiskelaboratoriet i Lysekil, 329, (ISSN: 1103-4777).

Madsen, N. (2007). Selectivity of fishing gears used in the Baltic Sea cod fishery. Reviews in Fish Biology and Fisheries, 17, 517-544.

Madsen, N., \& Valentinsson, D. (2010). Use of selective devices in trawls to support recovery of the Kattegat cod: A review of experiments and experience. ICES Journal of Marine Science 67(9), 2042-2050.

Madsen, N., Moth-Poulsen, T., Lowry, N. (1998). Selectivity experiments with window codends fished in the Baltic Sea cod (Gadus morhua) fishery. Fisheries Research, 36, 1-14.

Madsen, N., Holst, R., Foldager, L. (2002). Escape windows to improve the size selectivity in the Baltic cod trawl fishery. Fisheries Research 57, 223-235.

Madsen, N., Tschernij, V., Holst, R. (2010). Improving selectivity of the Baltic cod trawl fishery: Experiments to assess the next step. Fisheries Research 103, 40-47.

Madsen, N., Hansen, K., Madsen, N.A.H. (2015). Behavior of different trawl codends concepts. Ocean Engineering 108, 571-577.

Mortensen, L.O., Ulrich, C., Eliasen, S., Olesen, H.J. (2017). Reducing discards without reducing profit: free gear choice in a Danish result-based management trial. ICES Journal of Marine Science, 74 (5), 1469-1479.

MRAG. (2007). Impact assessment of discard policy for specific fisheries. European commission studies and pilot projects for carrying out the common fisheries policy no. FISH/2006/17 - Lot 1, Brussels. 289 pp.

Nielsen, E.E., Hansen, M.M., Ruzzante, D.E., Meldrup, D., Grønkjær, P. (2003). Evidence of a hybrid-zone in Atlantic cod (Gadus morhua) in the Baltic and the Danish Belt Sea revealed by individual admixture analysis. Molecular Ecology, 12, 1497-1508.

Nielsen, E.E., Grønkjær, P., Meldrup, D., Paulsen, H. (2005). Retention of juveniles within a hybrid zone between North Sea and Baltic Sea Atlantic cod (Gadus morhua). Canadian Journal of Fisheries and Aquatic Sciences, 62, 2219-2225.

Nilsson, H.C. (Ed). (2018). Sekretariatet för selektivt fiske-Rapportering av 2016 och 2017 års verksamhet. Aqua reports 2018:4. Swedish University of Agricultural Sciences, Department of Aquatic Resources, Lysekil, 211 pp. ISBN: 978-91-576-9557-4 (electronic version).

Nilsson, H.C., Andersson, E., Hedgärde, M., Königson, S., Ljungberg, P., Lunneryd, S-G., et al. (2018). Projects accomplished by the selective fisheries secretariat 2014-2017: A synthesis report, Aqua reports 2018:13, Swedish University of Agricultural Sciences, Department of Aquatic Resources, Lysekil, 26 pp, ISBN: 978-91-576-9576-5 (electronic version).

Nuevo, M., Morgado, C., Sala, A. (this volume). Monitoring the implementation of the Landing Obligation: The last Haul programme. In S.S. Uhlmann, C. Ulrich, S.J. Kennelly (Eds.), The European Landing Obligation - Reducing discards in complex, multi-species and multijurisdictional fisheries. Cham: Springer.

O’Neill, F.G., Feekings, J., Fryer, R.G., Fauconnet, L., Afonso, P. (this volume). Discard avoidance by improving fishing gear selectivity: Helping the fishing industry help itself. In S.S. Uhlmann, C. Ulrich, S.J. Kennelly (Eds.), The European Landing Obligation - Reducing discards in complex, multi-species and multi-jurisdictional fisheries. Cham: Springer.

Ridderstad, G. (1915). A new construction of trawl-net intended to spare under-sized fish. Svenska Hydrografisk-Biologiska Kommisionens skrifter, 6, 1-21.

Robertson, J.H.B, \& Stewart, P.A.M. (1988). A comparison of size selection of haddock and whiting by square and diamond mesh codends. ICES Journal of Marine Science 44:148-161.

Scientific, Technical and Economic Committee for Fisheries (STECF). (2014). 45th Plenary meeting report for Scientific, Technical and Economic Committee for Fisheries (PLEN-1401). 86 pp. https://stecf.jrc.ec.europa.eu/reports/plenary 
Scientific, Technical and Economic Committee for Fisheries (STECF). (2016). Methods and data requirements for LO. (STECF-16-13). 95 pp. https://stecf.jrc.ec.europa.eu/reports/discards

Scientific, Technical and Economic Committee for Fisheries (STECF). (2017). Fisheries Dependent Information - Classic (STECF-17-09). 846 pp. https://stecf.jrc.ec.europa.eu/reports/effort

Suuronen, P., Kuikka, S., Lehtonen, E., Tschernij, V., Madsen, N., Holst, R. (2000.) Improving technical management in Baltic cod fishery (BACOMA). Final report (EC 4th framework programme, contract FAIR CT 96-1994). 106 pp.

Suuronen, P., Tschernij, V., Jounela, P., Valentinsson, D., Larsson, P.O. (2007). Factors affecting rule compliance with mesh size regulations in the Baltic cod trawl fishery. ICES Journal of Marine Science, 64(8), 1603-1606.

Svedäng, H., \& Hornborg, S. (2014). Fishing induces density-dependent growth. Nature Communications, 5, 4152.

Tschernij, V., \& Holst, R. (1999). Evidence of factors at vessel-level affecting codend selectivity in Baltic cod demersal fishery. ICES CM 1999/R: 02.

Tschernij, V, Larsson, P.O., Suuronen, P., Holst, R. (1996). Swedish trials in the Baltic Sea to improve selectivity in demersal trawls. ICES CM 1996/B:2.

Tschernij, V., \& Suuronen, P. (2002). Improving trawl selectivity in the Baltic. TemaNord 2002: 512. $56 \mathrm{pp}$.

Tschernij, V, Suuronen, P, Jounela, P. (2004). A modelling approach for assessing short-term catch losses as a consequence of a mesh size increase. Fisheries Research, 69, 399-406.

Uhlmann, S.S., van Helmond, A.T.M., Stefánsdóttir, E.K., Siguroardóttir, S., Haralabous, J., Bellido, J.M., et al. (2014). Discarded fish in European waters: General patterns and contrasts. ICES Journal of Marine Science, 71, 1235-1245.

Valentinsson, D. (Ed). (2016). Sekretariatet för selektivt fiske- Rapportering av 2015-års verksamhet. Aqua Reports 2016:8. Swedish University of Agricultural Sciences, Department of Aquatic Resources, Lysekil, 126 pp. ISBN: 978-91-576-9403-4.

Valentinsson, D., \& Tschernij T. (2003). An assessment of a mesh size for the "Bacoma design" and traditional diamond mesh cod-end to harmonize trawl selectivity and minimum mesh size. ICES CM 2005/B:05.

Wienbeck, H., Herrmann, B., Moderhak, W., Stepputtis, D. (2011). Effect of netting direction and number of meshes around on size selection in the codend for Baltic cod (Gadus morhua). Fisheries Research, 109, 80-88.

Open Access This chapter is licensed under the terms of the Creative Commons Attribution 4.0 International License (http://creativecommons.org/licenses/by/4.0/), which permits use, sharing, adaptation, distribution and reproduction in any medium or format, as long as you give appropriate credit to the original author(s) and the source, provide a link to the Creative Commons license and indicate if changes were made.

The images or other third party material in this chapter are included in the chapter's Creative Commons license, unless indicated otherwise in a credit line to the material. If material is not included in the chapter's Creative Commons license and your intended use is not permitted by statutory regulation or exceeds the permitted use, you will need to obtain permission directly from the copyright holder.

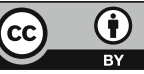

